\title{
Peningkatan Kreativitas Mahasiswa Menggunakan Model Project Based Learning dalam Pembuatan Media IPA Berbentuk Pop Up Book
}

\author{
Dea Mustika ${ }^{1}$, Siti Quratul Ain ${ }^{2}$ \\ Prodi PGSD, FKIP, Universitas Islam Riau, Indonesia ${ }^{1,2}$ \\ Email : deamustika@edu.uir.ac.id ${\text { quratulain@edu.uir.ac.id }{ }^{2}}^{1}$
}

\begin{abstract}
Abstrak
Penelitian ini berdasarkan pada hasil pengamatan pada proses pembelajaran yang menemukan bahwa masih rendahnya kreativitas mahasiswa dalam merancang media pembelajaran IPA. Penelitian ini merupakan Penelitian Tindakan Kelas yang bertujuan untuk mendeskripsikan peningkatan kreativitas mahasiswa menggunakan model project based learning dalam pembuatan media IPA berbentuk pop up book. Metode yang digunakan adalah kualitatif dan kuantitatif yang mana data yang didapat berupa persentase untuk kemudian dideskripsikan. Hasil dari penelitian ini menunjukkan adanya peningkatan kreativitas mahasiswa yang ditinjau dari aktivitas dan produk yang dihasilkan. Dari segi aktivitas pada siklus I diperoleh nilai rata-rata untuk keseluruhan aspek kreativitas adalah 70\% dan meningkat pada siklus II menjadi 83\%, sedangkan dari segi produk pada siklus I diperoleh nilai rata-rata $72 \%$ meningkat pada siklus II menjadi $82 \%$. Dapat disimpulkan bahwa telah terjadi peningkatan kreativitas mahasiswa dalam pembuatan media IPA berbentuk pop up book dengan menggunakan model project based learning.
\end{abstract}

Kata kunci: kreativitas, project based learning, pop up book

\begin{abstract}
This study is based on the results of observations on the learning process which found that student creativity was still low in designing media learning of science. This research is a Classroom Action Research. This study aimed to describe the improvement of student creativity using a project based learning model in making pop-up books of media learning science. The methods used are qualitative and quantitative. The results of this study indicate an increase in student creativity in terms of the activities and products produced. In terms of activity in the first cycle, the average value for all aspects of creativity was $70 \%$ and increased in the second cycle to $83 \%$. In terms of products in the first cycle, the average value of $72 \%$ increased in the second cycle to $82 \%$. It can be concluded that there has been an increase in student creativity in making pop-up books of media learning science using a project based learning model.
\end{abstract}

Keywords: creativity, project based learning, pop up book

Copyright (c) 2020 Dea Mustika, Siti Quratul Ain

$\triangle$ Corresponding author

Address : Universitas Islam Riau

Email : deamustika@edu.uir.ac.id

ISSN 2580-3735 (Media Cetak)

Phone :

ISSN 2580-1147 (Media Online)

DOI: https://doi.org/10.31004/basicedu.v4i4.518 
1168 Peningkatan Kreativitas Mahasiswa Menggunakan Model Project Based Learning dalam Pembuatan Media IPA Berbentuk Pop Up Book - Dea Mustika, Siti Quratul Ain

DOI: https://doi.org/10.31004/basicedu.v4i4.518

\section{PENDAHULUAN}

Kreativitas dapat menjadi bekal bagi mahasiswa calon guru agar kelak dapat merencanakan serta melaksanakan kegiatan pembelajaran yang bermakna di sekolah. Munandar (2018:25) menyatakan kreativitas merupakan kemampuan menciptakan sesuatu yang baru bermakna sosial. Pada program studi PGSD FKIP UIR upaya untuk mengembangkan kreativitas mahasiswa telah dijadikan sebagai bagian dari kegiatan pembelajaran. Mata kuliah yang diajarkan pada mahasiswa dirancang agar mahasiswa tidak hanya fasih dalam teori tetapi juga mengembangkan kreativitas yang ada di dalam diri. Salah satu mata kuliah yang mengupayakan pengembangan kreativitas mahasiswa adalah mata kuliah pendidikan IPA SD. Pada mata kuliah ini mahasiswa diberi kesempatan untuk menganalisis berbagai materi IPA yang terdapat di sekolah dasar mulai dari kelas rendah hingga kelas tinggi untuk kemudian diarahkan pada kemampuan merancang media pembelajaran yang tepat untuk dijadikan sebagai alat bantu pengajaran.

Berdasarkan pengamatan dan pengalaman dalam pembelajaran mata kuliah Pendidikan IPA $\mathrm{SD}$, media pembelajaran yang dibuat oleh mahasiswa selalu berupa alat peraga yang memanfaatkan potongan gambar untuk kemudian ditempelkan pada kertas karton dan diberi penjelasan seadanya. Alat peraga ini kemudian diberi pengait agar dapat digantungkan. Permasalahan yang serupa juga dikemukakan dalam penelitian Mustika, dkk (2020:33) yang menyatakan bahwa media pembelajaran berupa alat peraga gantung nyatanya tidak selalu efektif diterapkan dalam menjelaskan beberapa konsep dalam pembelajaran IPA terutama pada materimateri IPA yang sifatnya abstrak dan membutuhkan penjelasan lebih dari sekedar tempelan potongan gambar. Penyebab munculnya permasalahan ini tentu saja tak lepas dari model pembelajaran yang diterapkan. Selama ini dalam perkuliahan dosen lebih dominan menggunakan model pembelajaran yang berfokus pada presentasi. Mahasiswa kurang diberi arahan yang jelas bentuk media pembelajaran yang dapat dirancang untuk mendukung penjelasan hasil analisis materi-materi IPA di sekolah dasar. Hasil observasi pra siklus dengan menggunakan lembar observasi kreativitas diperoleh persentase rata-rata kreativitas mahasiswa adalah $49 \%$ untuk aktivitas, sedangkan untuk media pembelajaran yang dihasilkan diperoleh persentase rata-rata $58 \%$. Hasil ini menunjukkan masih kurangnya kreativitas mahasiswa terutama dalam merancang media pembelajaran IPA.

Salah satu model pembelajaran yang dapat diterapkan untuk meningkatkan kreativitas mahasiswa adalah model Project Based Learning (PjBL). Menurut Wena (2016:145) beberapa karakterisitik dalam model PjBL diantaranya (1) membuat kerangka kerja, (2) terdapat masalah, (3) adanya rancangan proses untuk mencapai hasil, (4) adanya tanggung jawab dalam mengelola informasi, (5) adanya evaluasi, (6) hasil akhir berupa produk. Pada penerapan pembelajaran dengan model $\mathrm{PjBL}$ pemberian tugas proyek menjadi tugas utama untuk menghasilkan pemahaman yang menyeluruh. Langkah-langkah 
1169 Peningkatan Kreativitas Mahasiswa Menggunakan Model Project Based Learning dalam Pembuatan Media IPA Berbentuk Pop Up Book - Dea Mustika, Siti Quratul Ain

DOI: https://doi.org/10.31004/basicedu.v4i4.518

model PjBL dikembangkan oleh The George Lucas Educational (dalam Kemendikbud 2013:32) yaitu :

1. Start with essential question (penentuan pertanyaan mendasar)

2. Design a plan for the project (mendesain perencanaan proyek)

3. Create a schedule (menyusun jadwal)

4. Monitor the students and the progress of the project (monitor kemajuan proyek)

5. Assess the outcome (menguji proses dan hasil belajar)

6. Evaluate the experience (melakukan evaluasi pengalaman)

Penerapan pembelajaran dengan menggunakan model PjBL memberikan kesempatan pada mahasiswa untuk aktif dalam memecahkan suatu masalah sehingga dapat menumbuhkan kreativitas di dalam diri, khususnya kreatif dalam merancang media pembelajaran. Menurut Asyhar (2014:47) media pembelajaran adalah segala sesuatu yang dapat menyampaikan pesan dari suatu sumber secara terencana sehingga penerima dapat melakukan proses belajar secara efisien dan efektif. Media pembelajaran tidaklah harus selalu dibuat dengan alat dan bahan yang mahal, tetapi media pembelajaran juga dapat dibuat dengan menggunakan alat dan bahan sederhana yang tetap mempunyai makna.

Salah satu media pembelajaran yang dapat dirancang sendiri untuk mendukung keterlaksanaan proses pembelajaran yang efektif adalah media pembelajaran berbentuk pop up book. Pop up book merupakan media berbentuk buku 3 dimensi yang apabila dibuka maka bagian dalamnya dapat terbuka memberikan kesan nyata. Dewanti,dkk (2018:224) menyatakan media pop up book dapat mengembangkan kreativitas dan memudahkan menangkap makna melalui perwakilan gambar yang menarik, selain itu pop up book juga memunculkan keinginan untuk membaca. Dengan kata lain, media pop up book memiliki daya tarik tersendiri bagi yang membaca untuk mempelajarinya lebih dalam lagi.

Berdasarkan uraian di atas, tujuan dari penelitian ini adalah untuk mendeskripsikan peningkatan kreativitas mahasiswa menggunakan model PjBL dalam pembuatan media IPA berbentuk pop up book. Peningkatan kreativitas dilihat dari aktivitas serta produk media pop up book yang mahasiswa hasilkan. Dengan dilakukannya penelitian ini diharapkan akan membawa manfaat bagi pengembangan kreativitas mahasiswa terutama dalam merancang dan membuat media pembelajaran yang mempunyai nilai makna edukatif.

\section{METODE}

Penelitian ini merupakan penelitian tindakan kelas dengan desain penelitian menggunakan model Kemmis dan Mc. Taggart. Penelitian terdiri dari dua siklus yang mana setiap siklusnya terdiri dari empat pertemuan. Rancangan penelitian dilakukan dalam empat tahapan utama yaitu perencanaan, pelaksanaan, observasi dan refleksi. Sebelumnya juga dilakukan observasi awal dengan mengamati dan menganalisa permasalahan yang muncul untuk kemudian dirumuskan menjadi permasalahan dalam penelitian. Pengukuran 
1170 Peningkatan Kreativitas Mahasiswa Menggunakan Model Project Based Learning dalam Pembuatan Media IPA Berbentuk Pop Up Book - Dea Mustika, Siti Quratul Ain

DOI: https://doi.org/10.31004/basicedu.v4i4.518

kreativitas dilakukan dengan pertimbangan subjektif karena jumlah subjek yang terbatas.

Penelitian dilaksanakan dalam mata kuliah Pendidikan IPA SD prodi PGSD FKIP UIR. Pengambilan sampel penelitian dengan teknik purposive sampling memutuskan bahwa subjek dalam penelitian ini adalah mahasiswa semester 4 kelas B yang berjumlah 49 orang. Alasan pemilihan kelas 4/B dikarenakan semua mahasiswa pada kelas 4/B mengambil mata kuliah Pendidikan IPA SD. Peran peneliti dalam penelitian adalah sebagai praktisi, penganalisis data dan pelapor sebagai hasil tindakan penelitian. Selain itu, peneliti juga dibantu oleh teman sejawat yang bertindak sebagai observer dan mengambil catatan lapangan yang dibutuhkan.

Teknik pengumpulan data berupa non tes dengan instrumen yang digunakan adalah angket dan lembar observasi. Angket ditujukan untuk mengukur kreativitas dari segi aktivitas dan lembar observasi ditujukan untuk mengukur kreativitas dari segi produk. Dalam penyusunan instrumen terlebih dahulu disusun kisi-kisi instrumen berdasarkan aspek kreativitas yang telah ditentukan. Kemudian diuraikan menjadi butir pernyataan menggunakan pernyataaan positif dengan dua pilihan jawaban yaitu Ya (1) dan Tidak (0).

Data yang diperoleh kemudian dianalisis menggunakan model analisis data kualitatif dan analisis data kuantitatif. Menurut Kunandar (2018:101) Analisis data kualitatif dilakukan secara berulang-ulang, dimulai sejak awal pengumpulan data. Data yang terkumpul direduksi untuk diseleksi dan dikelompokkan sesuai dengan fokus. Data yang tidak sesuai dihilangkan untuk selanjutnya disajikan dengan cara penyusunan informasi data. Kesimpulan diambil berdasarkan data yang disajikan dan menjadi kegiatan akhir dari penelitian. Penarikan kesimpulan dilakukan pada setiap akhir siklus yang dilaksanakan.

Data kuantitatif dianalisis menggunakan analisis statistik deskriptif dengan rumus teknik persentase dikemukakan oleh Trianto (2019:241) :

$$
K B=\frac{T}{T t} \times 100 \%
$$

Keterangan :

$$
\begin{aligned}
& \mathrm{KB}=\text { Ketuntasan Belajar } \\
& \mathrm{T}=\text { Jumlah skor yang diperoleh } \\
& \mathrm{Tt}=\text { Jumlah skor total }
\end{aligned}
$$

Penafsiran besarnya nilai yang diperoleh, mengadopsi kriteria yang dikemukakan Purwanto (2016:103) yaitu :

Tabel 1. Penafsiran Persentase Kategori Kreativitas

\begin{tabular}{|c|c|}
\hline$(\%)$ & Kategori \\
\hline $0-54$ & Sangat kurang \\
\hline $55-59$ & Kurang \\
\hline $60-74$ & Cukup \\
\hline $75-84$ & Baik \\
\hline $85-100$ & Sangat baik \\
\hline
\end{tabular}

Depdikbud (dalam Trianto, 2019, p. 241) menyatakan ketuntasan individu dapat ditentukan apabila proporsi jawaban benar $\geq 65 \%$ dan ketuntasan klasikal ditentukan apabila $\geq 85 \%$ tuntas dalam belajar. Berdasarkan hal tersebut maka dalam penelitian ini ditargetkan $75 \%$ mahasiswa mampu mencapai kategori baik untuk masingmasing aspek kreativitas baik dari segi aktivitas 
1171 Peningkatan Kreativitas Mahasiswa Menggunakan Model Project Based Learning dalam Pembuatan Media IPA Berbentuk Pop Up Book - Dea Mustika, Siti Quratul Ain

DOI: https://doi.org/10.31004/basicedu.v4i4.518

maupun produk dan $85 \%$ dari jumlah mahasiswa mencapai ketuntasan klasikal dengan nilai rata-rata adalah 75 , sehingga penelitian disimpulkan berhasil.

\section{HASIL DAN PEMBAHASAN}

Kegiatan pra siklus pada penelitian ini dilaksanakan sebelum diberlakukannya kebijakan study for home karena merebaknya pandemi COVID 19. Pada kegiatan pra siklus peneliti mengumpulkan data menggunakan lembar observasi kreativitas untuk mengetahui tindakan yang diberikan. Hasil pada kegiatan pra siklus adalah nilai rata-rata keseluruhan aspek kreativitas mahasiswa dari segi aktivitas $49 \%$ kategori sangat kurang dan nilai rata-rata keseluruhan dari segi produk 58\% kategori kurang.

Selanjutnya pelaksanaan tindakan penelitian dilanjutkan dalam pembelajaran daring yang dibagi atas dua siklus. Pelaksanaan tindakan pada siklus I dilaksanakan sebanyak empat kali pertemuan. Kegiatan pada siklus I meliputi pada tahapan perencanaan, tindakan, observasi dan refleksi. Tahapan perencanaan dilaksanakan dengan kegiatan menyiapkan Rencana Pembelajaran, rancangan tugas proyek dan instrumen yang digunakan untuk pengambilan data penelitian.

Tahapan pelaksanaan dilakukan dengan mengaplikasikan tahapan model PjBL dalam kegiatan perkuliahan yang dilaksanakan secara daring. Pada tahap ini peneliti memanfaatkan grup Whatsapp dan Edmodo untuk diskusi dan berbagi materi dengan secara online dengan mahasiswa. Materi yang dibagikan berupa bahan ajar contoh pembuatan media pop up book. Mahasiswa dibimbing menentukan materi IPA kelas rendah yang dijadikan sebagai bahan untuk pembuatan pop up book. Peneliti juga menyebarkan angket kreativitas secara online untuk mengetahui aktivitas mahasiswa selama pengerjaan tugas. Hasil dari angket inilah yang digunakan untuk mengetahui peningkatan kreativitas mahasiswa dari segi aktivitas dalam pembuatan media pop up book.

Observasi berupa kegiatan pengamatan terhadap tindakan yang dilakukan menggunakan instrumen yang telah disiapkan. Observasi meliputi pada pengamatan kreativitas dari segi aktivitas diamati menggunakan angket dan pengamatan kreativitas dari segi produk diamati menggunakan lembar observasi. Pengamatan kreativitas menggunakan angket mengukur lima aspek kreativitas yang kemudian diuraikan menjadi 14 butir pernyataan. Pada tahap observasi peneliti bekerjasama dengan teman sejawat untuk memberikan penilaian. Rangkuman hasil pengamatan kreativitas yang ditinjau dari aktivitas dapat dilihat pada tabel 2 berikut.

Tabel 2. Hasil Kreativitas Segi Aktivitas Siklus I

\begin{tabular}{|l|l|c|c|}
\hline No & \multicolumn{1}{|c|}{ Aspek rasa } & Rerata (\%) & Kategori \\
\hline 1 & $\begin{array}{l}\text { Memiliki } \\
\text { ingin tahu }\end{array}$ & Cukup \\
\hline 2 & $\begin{array}{l}\text { Percaya diri dan } \\
\text { mandiri }\end{array}$ & 70 & Cukup \\
\hline 3 & $\begin{array}{l}\text { Tanggung jawab } \\
\text { dan komitmen }\end{array}$ & 68 & Cukup \\
\hline 4 & $\begin{array}{l}\text { Tekun dan tidak } \\
\text { mudah bosan }\end{array}$ & 72 & Cukup \\
\hline 5 & Kaya inisiatif & 69 & Cukup \\
\hline Rerata keseluruhan & 70 & Cukup \\
\hline Ketuntasan klasikal & \multicolumn{3}{|c|}{75} \\
\hline
\end{tabular}


1172 Peningkatan Kreativitas Mahasiswa Menggunakan Model Project Based Learning dalam Pembuatan Media IPA Berbentuk Pop Up Book - Dea Mustika, Siti Quratul Ain

DOI: https://doi.org/10.31004/basicedu.v4i4.518

Berdasarkan Tabel 2 dapat diamati bahwa rerata hasil perolehan kreativitas mahasiswa dari segi aktivitas berada pada kategori sedang. Dari 49 orang mahasiswa yang mengisi angket, 37 orang mendapatkan nilai skor $\geq 75$ sehingga diperoleh rerata untuk ketuntasan klasikal adalah $75 \%$.

Hasil pengamatan kreativitas dari segi produk menggunakan lembar observasi terdiri dari empat aspek dengan 8 butir pernyataan. Lembar observasi digunakan oleh observer untuk menilai hasil dari media pop up book yang dikirimkan mahasiswa melalui foto dan video di edmodo. Rangkuman hasil pengamatan kreativitas yang ditinjau dari produk pop up book yang dihasilkan dapat dilihat pada tabel berikut.

Tabel 3. Hasil Kreativitas Segi Produk Siklus I

\begin{tabular}{|l|l|c|c|}
\hline No & \multicolumn{1}{|c|}{ Aspek } & $\begin{array}{c}\text { Rerata } \\
(\%)\end{array}$ & Kategori \\
\hline 1 & $\begin{array}{l}\text { Kesesuaian gambar dan } \\
\text { ilustrasi }\end{array}$ & 74 & Cukup \\
\hline 2 & $\begin{array}{l}\text { Penyajian dan } \\
\text { Pengembangan materi }\end{array}$ & 71 & Cukup \\
\hline 3 & $\begin{array}{l}\text { Penggunaan bahasa } \\
\text { komunikatif }\end{array}$ & 70 & Cukup \\
\hline 4 & $\begin{array}{l}\text { Pemilihan dan } \\
\text { Pemaduan warna }\end{array}$ & 72 & Cukup \\
\hline \multicolumn{2}{|l|}{ Rerata keseluruhan } & 72 & Cukup \\
\hline \multicolumn{2}{|l|}{ Ketuntasan klasikal } & \multicolumn{2}{|l}{} \\
\hline
\end{tabular}

Pada Tabel 3 dapat diamati rerata kreativitas mahasiswa untuk setiap aspek kreativitas dari segi produk berada pada kategori sedang. Rerata keseluruhan untuk semua aspek adalah $72 \%$ kategori cukup. Dari 49 orang mahasiswa, 34 orang diantaranya memperoleh skor $\geq 5$ sehingga diperoleh rerata untuk ketuntasan klasikal adalah 69\%. Hasil dari observasi selanjutnya dijadikan sebagai bahan pertimbangan untuk tahapan refleksi.

Tahap refleksi dilakukan dengan menelaah dan mendiskusikan pengalaman yang muncul pada siklus I. Berdasarkan hasil refleksi peningkatan kreativitas mahasiswa yang ditinjau dari segi aktivitas didapatkan informasi bahwa mahasiswa kurang memahami bentuk media pop up book yang baik dikarenakan kurang jelasnya contoh dan petunjuk yang diberikan, selain itu penilaian dari segi produk teramati bahwa sebagain besar pop up book yang dibuat oleh mahasiswa masih kurang komunikatif karena kebanyakan masih berupa tempelan gambar yang disusun seperti buku dan minim penjelasan.

Pengolahan data pada siklus I mendapatkan hasil yang masih lebih rendah dari indikator keberhasilan yang ditetapkan. Peningkatan kreativitas dari segi aktivitas untuk setiap aspek kreativitasnya memperoleh rata-rata keseluruhan $70 \%$ dan dari segi produk memperoleh rata-rata keseluruhan $72 \%$ sedangkan indikator keberhasilan 75\%. Artinya ada kesenjangan 5\% dan 3\%. Ketuntasan klasikal peningkatan kreativitas dari segi aktivitas $75 \%$ dan dari segi produk $69 \%$ sedangkan indikator keberhasilan $85 \%$. Artinya untuk ketuntasan klasikal terdapat kesenjangan $10 \%$ dan $16 \%$. Oleh karena itu, tindakan penelitian dilanjutkan pada siklus II untuk mencapai ketuntasan yang ditargetkan.

Pelaksanaan tindakan pada siklus II dilaksanakan sebanyak empat kali pertemuan. Kegiatan pada siklus II meliputi pada tahapan perencanaan, tindakan, observasi dan refleksi. Tahapan perencanaan dilaksanakan dengan 
1173 Peningkatan Kreativitas Mahasiswa Menggunakan Model Project Based Learning dalam Pembuatan Media IPA Berbentuk Pop Up Book - Dea Mustika, Siti Quratul Ain

DOI: https://doi.org/10.31004/basicedu.v4i4.518

kembali menyiapkan Rencana Pembelajaran, rancangan tugas proyek dan instrumen yang digunakan untuk pengambilan data penelitian.

Tindakan pada siklus II dilakukan dengan kembali mengaplikasikan tahapan model PjBL dalam kegiatan perkuliahan yang dilaksanakan secara daring. Peneliti juga masih memanfaatkan grup Whatsapp dan Edmodo untuk diskusi dan berbagi materi dengan secara online dengan mahasiswa. Materi yang dibagikan berupa bahan ajar dilengkapi dengan video pembuatan media pop up book. Mahasiswa dibimbing menentukan materi IPA kelas tinggi untuk dijadikan sebagai bahan pembuatan pop up book pada siklus II. Peneliti kembali menyebarkan angket kreativitas secara online untuk mengetahui aktivitas mahasiswa selama pengerjaan tugas.

Tahap observasi pembelajaran dilakukan untuk mengamati peningkatan kreativitas mahasiswa ditinjau dari segi aktivitas dan produk yang dihasillkan. Pengamatan kreativitas menggunakan angket yang disebarkan secara online, sedangkan untuk mengamati peningkatan kreativitas dari segi produk menggunakan lembar observasi. Rangkuman hasil pengamatan kreativitas yang ditinjau dari aktivitas pada siklus II dapat dilihat pada Tabel 4 berikut.

Tabel 4. Hasil Kreativitas Segi aktivitas Siklus II

\begin{tabular}{|l|l|c|c|}
\hline No & \multicolumn{1}{|c|}{ Aspek } & Rerata (\%) & Kategori \\
\hline 1 & $\begin{array}{l}\text { Memiliki rasa } \\
\text { ingin tahu }\end{array}$ & 81 & Baik \\
\hline 2 & $\begin{array}{l}\text { Percaya diri dan } \\
\text { mandiri }\end{array}$ & 84 & Baik \\
\hline 3 & $\begin{array}{l}\text { Tanggung jawab } \\
\text { dan komitmen }\end{array}$ & 85 & $\begin{array}{c}\text { Sangat } \\
\text { baik }\end{array}$ \\
\hline 4 & $\begin{array}{l}\text { Tekun dan tidak } \\
\text { mudah bosan }\end{array}$ & 82 & Baik \\
\hline
\end{tabular}

\begin{tabular}{|l|l|c|c|}
\hline 5 & Kaya inisiatif & 86 & $\begin{array}{c}\text { Sangat } \\
\text { baik }\end{array}$ \\
\hline \multicolumn{2}{|c|}{ Rerata keseluruhan } & 83 & Baik \\
\hline Ketuntasan klasikal & \multicolumn{2}{|c|}{92} \\
\hline
\end{tabular}

Berdasarkan Tabel 4 dapat diamati bahwa rerata hasil perolehan kreativitas mahasiswa dari segi aktivitas berada pada kategori baik. Dari 49 orang mahasiswa, 45 orang mendapatkan nilai skor $\geq 75$ sehingga diperoleh rerata untuk ketuntasan klasikal adalah $92 \%$.

Hasil pengamatan kreativitas dari segi produk menggunakan lembar observasi. Mahasiswa mengirimkan laporan dan video pop up book yang telah dibuat pada edmodo. Rangkuman hasil pengamatan kreativitas segi dari produk dapat dilihat pada tabel berikut.

Tabel 5. Hasil Kreativitas Segi Produk Siklus II

\begin{tabular}{|l|l|c|c|}
\hline No & \multicolumn{1}{|c|}{ Aspek } & Rerata (\%) & Kategori \\
\hline 1 & $\begin{array}{l}\text { Kesesuaian } \\
\text { gambar dan } \\
\text { ilustrasi dangat } \\
\text { baik }\end{array}$ \\
\hline 2 & $\begin{array}{l}\text { Penyajian dan } \\
\text { Pengembangan } \\
\text { materi }\end{array}$ & 84 & Baik \\
\hline 3 & $\begin{array}{l}\text { Penggunaan } \\
\text { bahasa } \\
\text { komunikatif }\end{array}$ & 79 & Baik \\
\hline 4 & $\begin{array}{l}\text { Pemilihan dan } \\
\text { Pemaduan warna }\end{array}$ & 82 & Baik \\
\hline Rerata keseluruhan & 82 & Baik \\
\hline Ketuntasan klasikal & \multicolumn{2}{|c|}{} \\
\hline
\end{tabular}

Hasil dari Tabel 5 dapat diamati rerata kreativitas mahasiswa untuk setiap aspek kreativitas dari segi produk berada pada kategori baik - sangat baik. Rerata keseluruhan untuk semua aspek adalah $82 \%$ kategori baik. Dari 49 orang mahasiswa 43 orang diantaranya 
1174 Peningkatan Kreativitas Mahasiswa Menggunakan Model Project Based Learning dalam Pembuatan Media IPA Berbentuk Pop Up Book - Dea Mustika, Siti Quratul Ain

DOI: https://doi.org/10.31004/basicedu.v4i4.518

memperoleh skor $\geq 75$ sehingga diperoleh rerata untuk ketuntasan klasikal adalah $87 \%$.

Tahap refleksi pada siklus II didapatkan informasi bahwa walau belum semua mahasiswa menunjukkan pencapaian sempurna untuk setiap aspek kreativitas yang diukur tetapi secara keseluruhan hasil yang didapatkan oleh mahasiswa telah mencapai indikator keberhasilan yang ditetapkan. Perbandingan peningkatan kreativitas mulai dari tahap pra siklus hingga siklus II dapat dilihat pada gambar berikut.

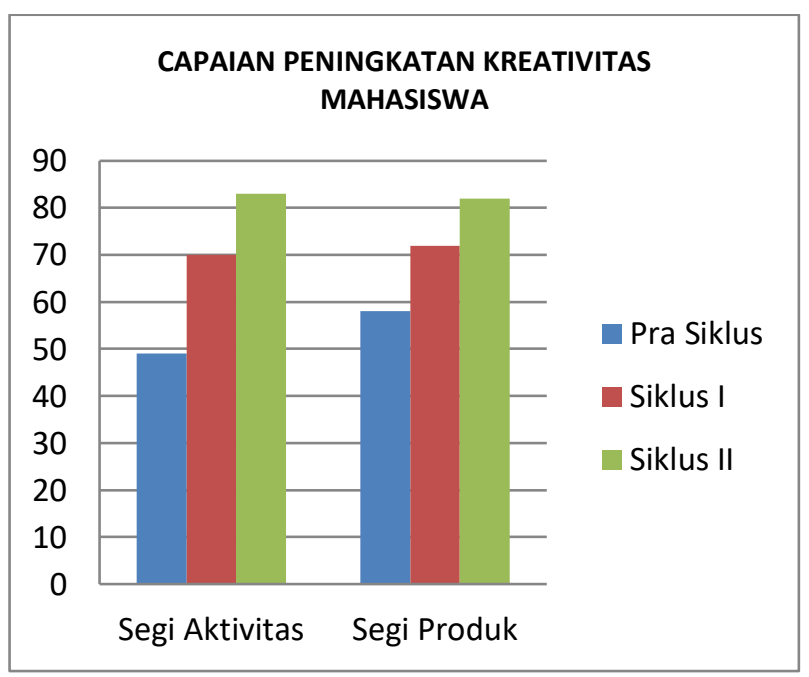

Gambar 1. Capaian Peningkatan Kreativitas Mahasiswa dari Pra Siklus hingga Siklus II

Berdasarkan gambar di atas dapat dilihat peningkatan kreativitas yang telah dicapai pada pelaksanaan kegiatan penelitian ini. Hasil dari pengolahan data mulai dari pra siklus hingga siklus II telah mencapai target yang ditentukan sehingga kegiatan penelitian dapat dicukupkan dan dilakukan penarikan kesimpulan. Penelitian ini membuktikan bahwa telah terjadi peningkatan kreativitas mahasiswa menggunakan model PjBL dalam pembuatan media IPA berbentuk pop up book.

\section{SIMPULAN}

Kegiatan pembelajaran pada penelitian ini dilaksanakan secara daring dengan memanfaatkan tahapan model Project Based Learning (PjBL) dan dilaksanakan dalam dua siklus yang setiap siklusnya terdiri dari empat pertemuan. Produk yang dihasilkan dalam penelitian ini berupa media pembelajaran IPA berbentuk pop up book tiga dimensi.

Peningkatan kreativitas yang dinilai pada penelitian ini ditinjau dari segi aktivitas dan segi produk dengan menerapkan tahapan model Project Based Learning dalam pembuatan media IPA berbentuk pop up book. Berdasarkan hasil penelitian yang telah dipaparkan didapatkan perbandingan peningkatan kreativitas mahasiswa baik dari segi aktivitas maupun produk yang dihasilkan. Rata-rata keseluruhan untuk setiap aspek kreativitas dari segi aktivitas pada pra siklus $49 \%$ meningkat pada siklus I 70\% hingga siklus II $83 \%$. Rata-rata keseluruhan untuk setiap aspek dari segi produk pada pra siklus $58 \%$ meningkat pada siklus I $72 \%$ hingga siklus II $82 \%$. Hasil dari kegiatan penelitian ini menyimpulkan bahwa terjadi peningkatan kreativitas mahasiswa menggunakan model $\mathrm{PjBL}$ dalam pembuatan media IPA berbentuk pop up book.

Harapannya dengan adanya kegiatan penelitian ini dapat membuat mahasiswa PGSD, sebagai calon guru lebih kreatif lagi dalam mengembangkan potensi diri untuk menghasilkan berbagai media pembelajaran. Dibutuhkan latihan 
1175 Peningkatan Kreativitas Mahasiswa Menggunakan Model Project Based Learning dalam Pembuatan Media IPA Berbentuk Pop Up Book - Dea Mustika, Siti Quratul Ain

DOI: https://doi.org/10.31004/basicedu.v4i4.518

yang berkesinambungan untuk memunculkan

kreativitas dalam diri mahasiswa agar benar-benar

dapat memahami berbagai bentuk media

pembelajaran yang dapat dimanfaatkan untuk

mendukung proses pembelajaran bagi siswa di

sekolah dasar.

\section{DAFTAR PUSTAKA}

Asyhar Rayandra. 2014. Kreatif Mengembangkan Media Pembelajaran. Jakarta: Referensi. Jakarta: Referensi.

Dewanti, Handaruni, Anselmus J. E. Toenlioe, and Yerry Soepriyanto. 2018. "Pengembangan Media Pop-Up Book Untuk Pembelajaran Lingkungan Tempat Tinggalku Kelas IV SDN 1 Pakuaden Kabupaten Ponorogo." Jurnal Kajian Teknologi Pendidikan 1(3):221-28.

Kemendikbud. 2013. Peraturan Menteri Pendidikan Dan Kebudayaan Republik Indonesia Nomor 65 Tahun 2013 Tentang Standar Proses Pendidikan Dasar Dan Menengah. Jakarta.

Kunandar. 2018. Langkah Mudah Penelitian Tindakan Kelas. Jakarta: Rajawali Pers.

Munandar, Utami. 2018. Pengembangan Kreativitas Anak Berbakat. Jakarta: Rineka Cipta.

Mustika, Dea, Dafit Febrina, and Vany Sinthya. 2020. "Peningkatan Kreativitas Mahasiswa Dalam Pembuatan Alat Peraga IPA Menggunakan Pembelajaran Berbasis Proyek." 3(1):31-48.

Purwanto. 2016. Evaluasi Hasil Belajar. Yogyakarta: Pustaka Pelajar.

Trianto. 2019. Model Pembelajaran Terpadu. Jakarta: Bumi Aksara.

Wena Made. 2016. Strategi Pembelajaran Inovatif Kontemporer. Jakarta: Bumi Aksara. 